\title{
JOHN SHEVELAND
}

\section{Gonzaga University}

For this inaugural issue of Interreligious Studies and Intercultural Theology, we include nine brief statements on the nature, scope, andstatus of intercultural theology from a diverse range of authors in the field. Four of them are Europeans teaching in Birmingham, Amsterdam, Frankfurt, and Salzburg, while a fifth is an Austrian teaching in New Orleans. One author is a white American, another a Japanese-German American, one Asian-American, and another is a Malaysian trained in the Netherlands and teaching in Australia. Our intention quite simply was to solicit from this impressive group of scholars their own disciplinary, regional, and cultural understandings of the relationship between "intercultural theology" and related disciplines like missiology, systematic theology, world Christianity, interreligious dialogue and ecumenism. Their inventory of responses demonstrate a far-ranging discipline with repeated moments of overlapping consensus of common concern and purpose (for example, addressing global nationalisms and far-right populisms) and of hermeneutical perspective toward the Christian past, especially toward mission and missiology (for example, post-colonial sensitivity to forms of cultural and religious hegemony).

Schreiter, Chia, and Gmainer-Panzl question the role of power in naming the interplay of theology and culture, but they assess terms differently. Gmainer-Panzl locates intercultural theology within systematic theology, as its widening lens, whereas Yong and Gruber recommend the internalization of intercultural material throughout the various subdisciplines of theology. For Schreiter, the terminology of intercultural theology intones a third space - the inter-which reciprocally illumines both sides, which for him render unreflective positing of terms like world Christianity or global Christianity resonant with an imperial Christendom or colonial Christianity. Chia, in contrast, celebrates world Christianity as an adequate term to unseat Western normativity through acknowledgment that non-Western Christianities exist in their own right and not as an extension of the West. Concerned that "intercultural theology" may retain 
aspects of Western hegemony, Paas seeks to secure polycentrism through designations like "world theology" and "planetary theology," signifying a world without clear centers giving rise to "mission from everywhere to everywhere." Analogously, these concerns for the subaltern find a compliment in Tiemeier, who recalls how, historically, interreligious dialogues have privileged white, male dialoguers and excluded persons of color.

Importantly, Yong and Gruber challenge other theologians to recognize that "intercultural theology" specifies a scholarly orientation whereby theologians seek to reconstitute the various sub-disciplines of theology in an intercultural key and seek to perform what Gruber calls a "powercritical reading across the theological canon," averting the temptation to outsource intercultural theology to an independent discipline. In these ways and more, this roundtable discussion reports on many live issues and constructive opportunities in intercultural theology today.

$\overline{\text { John N} \text {. Sheveland is an Associate Professor of Religious Studies and currently serves as a }}$ board member of the Society of Buddhist-Christian Studies and on the steering committee of the Interfaith and Interreligious Studies group of the American Academy of Religion.

(C) Equinox Publishing Ltd. 2017

\section{eevinoxonline}

